\title{
DOES TOURISM ACTIVITY AFFECT MIGRATION? EMPIRICAL EVIDENCE FROM CROATIA
}

\author{
Neven Ivandić
}

https://doi.org//10.20867/tosee.06.24

\begin{abstract}
Purpose - Since the Census in 2011, Croatia has seen a substantial population decline. Given the high contribution of tourism to the Croatian economy, this paper empirically analyses the relationship between population migration, namely total net migration and net migration abroad, and tourism activity.

Methodology - The research design of this paper is based on quantitative econometric panel data analysis using annual data for cities and municipalities in Croatia between 2002 and 2019. A oneway and two-way fixed effects model are used for the estimation of the regression model coefficients.

Findings - The set models provide insight into the relationship between net migration or migration abroad and tourism activity. Tourism can be seen as a generator of demographic change, especially in rural and less developed areas, as it generates employment opportunities and, thus, the opportunity for permanent residency.

Contribution - The main contribution of this paper is the novel use of such detailed data at the geographical level that spans over two decades. This generates empirical insights that hold high levels of external validity. A further important aspect of the paper is the analysis of the connection between population migration and tourism activity in the context of Croatia's accession to the European Union and verification of the theoretically grounded expectation that tourism activity as pull factor is positively related to population net migration.
\end{abstract}

Keywords: population, migration, tourism, Croatia, panel.

\section{INTRODUCTION}

The European Union (EU) is facing a surge in the influx of migrants, which brings with it a number of questions such as the reception capacity, solving of labour market shortages and the safety of people searching for the opportunity for a better life or protection (European Commission 2020).

At the beginning of 2020, 23 million persons were living in the EU, or $5.1 \%$ of the population of the Union, with citizenship of an EU non-member country and 13.5 million persons who lived in EU member states and were citizens of some other EU member states. The most receptive countries in the EU are Germany, in which at the beginning of 202010.4 million non-nationals were living, then Spain (5.2 million), France (5.1 million) and Italy (5.0 million). These four countries comprise $58 \%$ of the total population of the $\mathrm{EU}$ and are the destination for $71 \%$ of the total number of non-nationals living in the combined EU member states. In 2019 the number of immigrants to the EU coming from non-EU countries rose by 2.7 million (Eurostat 2021). 
ToSEE - Tourism in Southern and Eastern Europe, Vol. 6, pp. 357-373, 2021.

N. Ivandić: DOES TOURISM ACTIVITY AFFECT MIGRATION? EMPIRICAL EVIDENCE FROM ...

An important impact on inter-EU country migration was made by the enlargement of the EU in 2004 and 2007, which, sparked by economic factors such as changes in GDP per capita and youth unemployment (Franc et al., 2019) generated, despite a number of institutional restrictions that were set up, strong migratory trends from the new to the old member states. Between 2003 and 2007, 3.1\% of working-age Lithuanians, 3.0\% of Cypriots, $2.5 \%$ of Romanians, $2.0 \%$ of Poles, $2.0 \%$ of Slovaks and 1.7\% of Bulgarians moved to another European country (Kahanec et al. 2009).

EU accession was accompanied in Croatia too by accelerated emigration of the population after 2013. The number of Croatian residents that moved abroad soared from 12,877 in 2012 to 40,148 in 2019, aggravating an already bad demographic situation (Akrap 2019). According to estimates of the Croatian Bureau of Statistics (CBS) the population of Croatia fell from 4.2678 million in 2012 to 4.065 million in 2019, in other words by $4.75 \%$ (CBS 2016; 2020b).

The reduction of the total population and the emigration of young and working-age citizens of Croatia is reflected in the reduction of productive potential and the potential for generating products with greater added value, loss of competitiveness and pressure on public finances (Goldner Lang and Lang 2019; Troskot et al. 2019). Due to the large negative consequences of emigration, this paper aims to shed light on the factors that can prevent negative net emigration. Given the very high contribution of tourism to the Croatian economy, as measured by internal tourism consumption as a proportion of total domestic supply (Eurostat 2019), and its seasonality and regional concentration on the Adriatic coast, the paper focuses on the two research questions. First, whether tourism activity affects internal net country migration (emigration - immigration) in Croatia. Second, whether tourism activity affects net international migration (emigrationimmigration) in Croatia.

The answers to these questions are based on the empirical analyses of the relationship between permanent population migration, namely total net migration and net migration abroad, and tourism activity based on quantitative econometric panel data analysis using annual data for cities and municipalities in Croatia between 2002 and 2019.

The paper consists of five parts. After the introduction, in the second part the theoretical framework of the determinants of migrations and the links between migrations and tourism are analysed. Part three shows the key characteristics of migrations in Croatia at the regional level. In part four, the parameters of two economic panel models are established, tested and evaluated and the results obtained are analysed. In part five the results of the analysis are summed up in the context of the methodological constraints of the research and key policy recommendations.

\section{MIGRATIONS AND TOURISM}

Understanding of the determinants of migrations, or a change in permanent residence, has been evolving since the time of Adam Smith, who connected mobility and the circulation of labour with unemployment and differences in wages, or rather, inadequate wages (Rauhut 2019). Lee (1966), in his seminal paper A Theory of Migration, has set 
ToSEE - Tourism in Southern and Eastern Europe, Vol. 6, pp. 357-373, 2021.

N. Ivandić: DOES TOURISM ACTIVITY AFFECT MIGRATION? EMPIRICAL EVIDENCE FROM ...

up a migration model according to which migration happens when positive reasons for migration outweigh negative ones. The model integrates (i) push factors that induce people to leave old residences, (ii) pull factors that induce people to move to a new location, (iii) intervening obstacles, and (iv) personal factors. The developed model thus recognizes the four driving forces that affect the reasons for emigration from origin areas and the reasons for attraction to destination areas, but also the factors that result from the connection of origin and destination areas and the factors that determine the attitudes of emigrants (Massey et al. 1999; Schewel 2020).

It is, therefore, possible to state that migration is affected by future expectations and a relative combination of a number of economic, social and cultural, security, ecological and personal factors in areas/countries of origin and receiving areas/countries, including the living standard, education, safety, political freedom, climate change, as well as transactional costs and restrictions on the process of migration.

The analysis of modern migration processes requires, consequently, the integration of different theoretical perspectives and assumptions such as differences in wages, the expectation of a positive net return from migration, collective decision-making which reflects the need to maximize expected risk but also to minimize the risk associated with different market failures. Understanding migration is also supported by theories that emphasize that migration decisions are socially contextualized and arise from intrinsic labor demands of developed market economies, but also that recognize the importance of migrant networks or the development of institutions supporting transnational movement (Massey et al. 1993).

In other words, the understanding of migration processes reflects the nexus of various aspects and causes of migrations, which can be brought down largely to the relation of push and pull factors (Kumpikaite and Zickute 2012), including the explanation of migrations between rural and urban spaces and the explanation of the influence of the dual labor market and understanding of the spatial aspects of migration, as well as of the recognition of the importance of qualifications, education, motivation and the decision making process and interpersonal connections and migrant networks.

Permanent migrations, as means of achieving an expected future personal or family optimisation of well-being and tourism are interrelated (Dwyer et al. 2014; Salazar 2020) but in a non-linear manner (Haas 2010). A number of topics attracted the attention of researchers such as tourism and labor migration, tourism and entrepreneur migration, tourism and return migration, tourism and retirement migration, as well as topics related to the context of social and economic circles including the impact of migration on tourism demand (Williams and Hall 2002; Toker and Kozak 2020). From the production perspective, permanent migrations are correlated with labour migrations that are the result of the demand for manpower generated by the tourist activity that cannot be supplied locally (Williams and Hall 2000), including demand generated by the multiplicative effects on other activities, such as construction, transport, industry and agriculture, commerce and so on. Reflecting the peripatetic lifestyle of migrants and their shifting between two or more homes, the consumption perspective includes circular or housing adjustment migration and amenity-led migration (Bell and Ward 2000) as well as the change of residence after retirement (Barbosa et al. 2020). 
ToSEE - Tourism in Southern and Eastern Europe, Vol. 6, pp. 357-373, 2021.

N. Ivandić: DOES TOURISM ACTIVITY AFFECT MIGRATION? EMPIRICAL EVIDENCE FROM ...

Migrants' abilities to become established in the destination are related to their mobility status, which reflects different levels of migrant social entry, including segments that range from former and resident migrants, highly skilled and business migrants, regular and temporary labour migrants to family-reunifying migrants and irregular migrants (World Tourism Organisation 2009). The capacity to attract migrants and to involve them in a destination community gains should be regarded from the perspective of the high labour turnover and the impact on the quality of the product and experience offered to tourists (Salazar 2020).

Attention is merited not only to the relationship-between tourism and migratory trends in developed tourist destinations but also to consideration of the possible influence of tourism on the attraction of new residents to rural communities by the generation of new jobs, and thus reducing negative social and economic trends that stem from the aging of the population, urbanisation and emigration of the young as well as economic restructuring (Vuin et al. 2016). The analysis of the relationship of tourism and migration in less developed areas indicates the positive effects that stem from increased inmigration but are accompanied by a restricted duration of residence in the destination and the inability of tourism to reduce out-migration (Möller and Amcoff 2018). A specific aspect of the linkage of migration and tourism is related to the return migration since migrants who have a preference for returning to their 'starting position' can have a positive effect on rural development by engaging in tourism (Santos 2019).

\section{MIGRATIONS IN CROATIA}

In 2019, according to official statistical estimates, Croatia had a population of 4.065 million, which is decreased by $5.05 \%$ as compared to 2011 (Table 1). After a slight rise in the population from 2002 to 2007 , the number of inhabitants has constantly diminished, a particularly vigorous fall coming after 2011. The most rapid reduction occurred in 2017 when the number of inhabitants was reduced by $1.2 \%$, and then in 2018 which recorded a fall of $0.9 \%$. The diminution of the population is the result of negative natural population trends and net migration of the population to other countries.

Table 1: Croatia: Total population, natural decrease, and migrant flows in 2001, 2011 and 2019

\begin{tabular}{lrrr}
\hline & 2002 & 2011 & 2019 \\
\hline Mid-year estimate of the total population & 4.302 .174 & $4,280,622$ & $4,065,253$ \\
Natural change of population & -10.475 & $-9,822$ & $-15,659$ \\
Immigrants from abroad & 20.365 & 8,534 & 37,726 \\
Emigrants abroad & 11.767 & 12,699 & 40,148 \\
\hline
\end{tabular}

Source: The Croatian Bureau of Statistics

The natural population trend was negative from 2002 to 2019. Migrations into and out of Croatia show diverse trends. The curve of the number of immigrants from abroad registers a U shape with its minimum in 2010. After 2010, the number of immigrants grew and was particularly enlarged between 2017 and 2019 (Graph 1). 
ToSEE - Tourism in Southern and Eastern Europe, Vol. 6, pp. 357-373, 2021.

Graph 1: Croatia: Changes in total population, a natural decrease of population, and number migrants to and from abroad from 2002 to 2019, base indices 2011=100

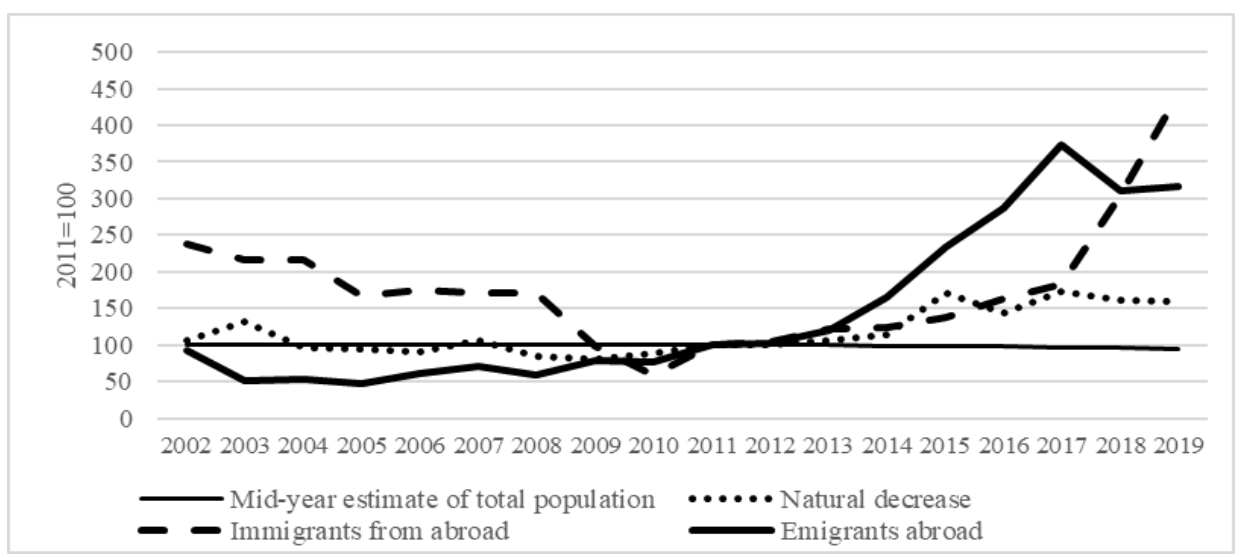

Source: The Croatian Bureau of Statistics

In line with official statistical data, the population of Croatia from 2011 to 2019 was cumulatively reduced by 120.5 thousand people for natural reasons (CBS 2020b) and by 111.3 thousand persons because of migration (CBS 2020a). It has to be pointed out that official emigration statistics, because of how migratory events are recorded and the tendency of emigrants not to report their emigration, potentially underestimate the real scale of emigration (Pavić and Ivanović 2019). In 2011, 12.7 thousand inhabitants moved out of Croatia, and 8.5 thousand people moved in. In 2019 the number of those who emigrated abroad reached 40.1 thousand, while there were 37.7 immigrants. A surge in emigration came in 2017 when 47.4 thousand members of the Croatian population moved out.

Table 2: Croatia NUTS 2* regions: Total population from 2011 to 2019, structure in percentage, year to year rate of change in \%

\begin{tabular}{lrrrrrrrrr}
\hline \multirow{2}{*}{ NUTS 2 regions* } & 2011 & 2012 & 2013 & 2014 & 2015 & 2016 & 2017 & 2018 & 2019 \\
\cline { 2 - 9 } & $1,411.2$ & $1,408.6$ & $1,406.9$ & $1,404.7$ & $1,397.4$ & $1,391.1$ & $1,381.9$ & $1,375.8$ & $1,373.9$ \\
\hline Adriatic Croatia & $1,223.8$ & $1,212.4$ & $1,201.4$ & $1,186.6$ & $1,164.4$ & $1,145.0$ & $1,113.4$ & $1,088.1$ & $1,068.7$ \\
Pannonian Croatia & 855.2 & 853.5 & 851.9 & 848.7 & 842.2 & 835.9 & 826.4 & 819.4 & 815.4 \\
North Croatia & 790.5 & 793.1 & 795.5 & 798.4 & 799.6 & 802.3 & 802.8 & 804.5 & 807.3 \\
City of Zagreb & & & & &
\end{tabular}

*According to the National classification of territorial units for statistics 2021 (HR_NUTS 2021.). Official Gazette 125/2019

Source: The Croatian Bureau of Statistics

The spatial distribution of changes in the size of the population varies essentially in terms of Croatian regions (Table 2). In the period from 2011 to 2019, the city of Zagreb, of the four analysed NUTS 2 regions of Croatia, alone registered a population growth: from 790.5 thousand to 807.3 thousand, or $2.1 \%$. At the same time, Adriatic Croatia, the NUTS 2 region with the highest population, underwent a population reduction of $2.6 \%$. The 
ToSEE - Tourism in Southern and Eastern Europe, Vol. 6, pp. 357-373, 2021.

N. Ivandić: DOES TOURISM ACTIVITY AFFECT MIGRATION? EMPIRICAL EVIDENCE FROM ...

biggest reduction in the number of inhabitants came in Pannonian Croatia, in which the population fell from 1,223.8 thousand in 2011 to $1,068.7$ thousand in 2019 , in other words by $12.7 \%$. North Croatia saw its population fall in that period by $4.7 \%$.

The falls in population recorded in NUTS 2 regions are not just the result of natural population changes and migrations abroad, but also of internal migrations. The rise of the population of the City of Zagreb, in the period from 2011 to 2019 is thus generated primarily by the migration of the population from other regions of Croatia. Cumulative net intra-Croatia migrations have generated an enlargement of the number of inhabitants of the city of Zagreb from 2011 to 2019 of 29.1 thousand residents.

Three counties in Adriatic Croatia had a positive influx from intra-Croatian migrations (Table 3). The biggest net population growth due to migration from other counties of the country came in the Istria, Zadar and Primorje-Gorski kotar counties. Other counties of Adriatic Croatia were from 2011 to 2019 an area of intra-Croatian net emigration, but with a relatively low proportion of net emigration as a proportion of the population in 2019, which ranged between $0.08 \%$ in Lika-Senj County $0.06 \%$ in Šibenik-Knin County. Istria County and Dubrovnik-Neretva Country experienced larger inflows from abroad in the period under analysis than outflows of inhabitants to other countries.

\section{Table 3: Croatia NUTS 2 and NUTS 3 regions: Population and migrations}

\begin{tabular}{|c|c|c|c|c|}
\hline \multirow{2}{*}{$\begin{array}{l}\text { NUTS } 2 * \text { and NUTS } 3 * \\
\text { (counties) regions }\end{array}$} & \multicolumn{2}{|c|}{$\begin{array}{l}\text { Mid-year estimate of the } \\
\text { total population } \\
\end{array}$} & \multirow{2}{*}{$\begin{array}{l}\text { Cumulative net** } \\
\text { migration from another } \\
\text { county 2011-2019 }\end{array}$} & \multirow{2}{*}{$\begin{array}{l}\text { Cumulative net**** } \\
\text { migration from } \\
\text { abroad 2011-2019 }\end{array}$} \\
\hline & 2011 & 2019 & & \\
\hline Adriatic Croatia & $1,411,152$ & $1,373,914$ & & $-11,564$ \\
\hline Primorje-Gorski kotar & 296,004 & 282,730 & 2,609 & $-5,038$ \\
\hline Lika-Senj & 50,697 & 44,625 & -36 & $-2,323$ \\
\hline Zadar & 170,212 & 168,213 & 3,763 & $-2,870$ \\
\hline Šibenik-Knin & 109,072 & 99,210 & -549 & $-4,480$ \\
\hline Split-Dalmatia & 454,683 & 447,747 & $-1,432$ & -153 \\
\hline Istria & 208,028 & 209,573 & 4,462 & 2,496 \\
\hline Dubrovnik-Neretva & 122,456 & 121,816 & -410 & 804 \\
\hline Pannonian Croatia & $1,223,813$ & $1,068,688$ & & $-74,000$ \\
\hline Sisak-Moslavina & 171,725 & 145,904 & $-5,921$ & $-12,496$ \\
\hline Karlovac & 128,495 & 115,484 & $-1,401$ & $-4,721$ \\
\hline Bjelovar-Bilogora & 119,448 & 106,258 & $-3,785$ & $-4,693$ \\
\hline Virovitica-Podravina & 84,621 & 73,641 & $-3,167$ & $-5,128$ \\
\hline Požega-Slavonia & 77,775 & 66,256 & $-3,041$ & $-6,347$ \\
\hline Slavonski Brod-Posavina & 158,249 & 137,487 & $-6,966$ & $-9,840$ \\
\hline Osijek-Baranja & 304,541 & 272,673 & $-6,248$ & $-16,194$ \\
\hline Vukovar-Sirmium & 178,959 & 150,985 & $-8,841$ & $-14,581$ \\
\hline North Croatia & 855,207 & 815,397 & & $-19,583$ \\
\hline Zagreb county & 317,594 & 309,169 & 5,846 & $-8,363$ \\
\hline Krapina-Zagorje & 132,672 & 124,517 & -423 & $-1,553$ \\
\hline Varaždin & 175,771 & 166,112 & -360 & $-3,416$ \\
\hline Međimurje & 113,746 & 109,232 & $-1,235$ & $-3,167$ \\
\hline Koprivnica-Križevci & 115,424 & 106,367 & $-1,990$ & $-3,084$ \\
\hline City of Zagreb & 790,450 & 807,254 & 29,125 & $-6,143$ \\
\hline
\end{tabular}

* According to National classification of territorial units for statistics 2021 (HR_NUTS 2021.). Official Gazette $125 / 2019$

$* *$ Net $=$ difference between number of immigrants from another counties and emigrants to another counties

$* * *$ Net $=$ difference between number of immigrants from abroad and emigrants to other countries

Source: The Croatian Bureau of Statistics 
ToSEE - Tourism in Southern and Eastern Europe, Vol. 6, pp. 357-373, 2021.

N. Ivandić: DOES TOURISM ACTIVITY AFFECT MIGRATION? EMPIRICAL EVIDENCE FROM ...

Three counties in Adriatic Croatia had a positive influx from intra-Croatian migrations (Table 3). The biggest net population growth due to migration from other counties of the country came in the Istria, Zadar and Primorje-Gorski kotar counties. Other counties of Adriatic Croatia were from 2011 to 2019 an area of intra-Croatian net emigration, but with a relatively low proportion of net emigration as a proportion of the population in 2019, which ranged between $0.08 \%$ in Lika-Senj County $0.06 \%$ in Šibenik-Knin County. Istria County and Dubrovnik-Neretva Country experienced larger inflows from abroad in the period under analysis than outflows of inhabitants to other countries.

In the counties of North Croatia, only Zagreb County, making use of the drawing power of the capital had a positive intra-Croatian migration. All of the counties of the region had a negative balance of migrations with other countries. The counties of Pannonian Croatia were from 2011 to 2019 the biggest emigration areas of Croatia. The highest net emigrations relative to the population size in 2019 were recorded in Vukovar-Sirmium County from which a net 5.86\% of the population moved out, as well as Slavonski BrodPosavina County which experienced a net loss of $5.07 \%$ of its population.

Except for the city of Zagreb and Zagreb Country, the regional analysis of migrations showed that, relative to the size of the population, the lowest net migration in the area of Adriatic Croatia. Since this is a region the economic structure of which to a large extent relies on the tourism activity and that in 2019 generated $94.6 \%$ of all overnight stays in Croatia (CBS, 2020c), the question arises as to whether tourism can be connected with the reduced propensity of the population to emigrate or by the greater attractive power for immigration. This is particularly important, since research into the factors that affect migrations within the EU, and migrations from Croatia, accordingly, indicates the importance, along with economic factors, such as differentials in wages and unemployment, of institutional factors such as working conditions and work ethics, irregular payment of wages, honesty, lack of political vision, nepotism, religious intolerance, nationalism and the absence of structural reforms (Goldner Lang and Lang 2019). The complexity in the relations of the factors that generate migrations and the relationship of migration and tourism is also shown by the migration trends in the three counties that in 2019 generated the greatest number of tourist overnight stays in Croatia:

- Istria County, the biggest tourist region of Croatia, cumulatively had a greater number of migrant arrivals, from other counties in Croatia and from abroad, than departures of the inhabitants. The population of the county in 2019 showed an increase of $2.1 \%$ since 2011 from intra-Croatian migrations and 1.2\% from migrations abroad.

- Split-Dalmatia County, in terms of numbers of overnights the second biggest region in Croatia, saw greater emigration than immigration, in terms of both intra-Croatian migrations and international migrations.

- Primorje-Gorski kotar County, the third biggest tourist region in terms of the number of overnights, increased the population by $0.9 \%$ from intra-Croatian migrations, but in terms of international migrations fell by $1.8 \%$. 
ToSEE - Tourism in Southern and Eastern Europe, Vol. 6, pp. 357-373, 2021.

N. Ivandić: DOES TOURISM ACTIVITY AFFECT MIGRATION? EMPIRICAL EVIDENCE FROM ...

\section{METHODOLOGY, DATA, AND RESULTS}

The theoretical framework of the analysis suggested possible aspects of the relationship of tourism and migration. Taking up existing theoretical and empirical research, in this section, the relationship between permanent population migration and tourism is analysed across small geographic areas in Croatia. The analysis is based on quantitative econometric panel data, using annual data for all cities and municipalities in Croatia between 2002 and 2019, which, considering the temporal dimension and the granular spatial level of the analysis, enables generalisation of the results of the analysis.

\subsection{The Model}

The empirical analysis of the relationship between permanent population migration and intensity of tourism activity is based on two models (Model I and Model II) which differ in the outcome variable. In the first model, overall net migration is used as an outcome variable, and in the second, net migration abroad. Both models use the same explanatory and control variables. The explanatory variable is the intensity of tourism activity measured by the number of overnight stays. The number of employees, as a proxy for total economic activity, and the number of kindergartens, as the proxy for the social standard and living quality, are used as control variables. Depending on the specification of the model, two additional control variables are used. The dummy variable that controls for the impact of Croatia's accession to the EU, and the dummy variable that controls for the impact of the 2008 and 2009 world economic recession, which has a value of zero in the period from 2002 to 2008 and from 2015-2019 and a value of 1 from 2009 to 2014 . The choice of control variables is influenced by the theoretical framework discussed in the previous section and the limited availability of harmonized data at the level of municipalities and cities in the selected time horizon.

Since the fixed effects model (Baltagi 2005) is an appropriate specification when focusing on a specific set of units, in this case, all administratively determined, Croatian municipalities and cities (units are not selected randomly), the models are specified as the fixed effects models. Two forms of the fixed effects model were tested:

- One-way fixed effect model - a model in which the constant changes with units, where the tested model specifications include dummy variables for Croatia's accession to the EU and the dummy variable for the 2008 and 2009 world economic recession

- Two-way fixed effect model - a model in which the constant changes with units and time (years) is used, where the tested model specifications through the year fixed effects captures the effect of EU accession and 2008 and 2009 world economic recession without the use of the dummy variables.

The justification for the use of the both one-way and two-way fixed effect model was checked by an F-test which tests the joint significance of model's dummies of years and geographic units. 
ToSEE - Tourism in Southern and Eastern Europe, Vol. 6, pp. 357-373, 2021. N. Ivandić: DOES TOURISM ACTIVITY AFFECT MIGRATION? EMPIRICAL EVIDENCE FROM ...

Specification of the variables used for analysis:

- $\Delta M_{i . t}$ [Net Migration] is the dependent variable defined as net migration from the municipality and or city $i$ in year $t$; net migration is defined as the difference between the number of in-migrating and out-migrating populations to and from the municipality or city in a given year

- $\Delta I M_{i, t}$ [Net International Migration] is the dependent variable defined as net international migration from municipality/city $i$ in year $t$; net international migration is defined as the difference between the numbers of inhabitants immigrating into the city/municipality from abroad and the number emigrating abroad in a given year

- $O_{i, t}$ [Tourist Nights] is the explanatory variable of the intensity of tourist activity measured by the number of overnight stays in the commercial capacities in municipality/city $i$ in year $t$, positive impact on overall and abroad migration is expected

- $E_{i, t}$ [Employment] is the control variable of the number of employees in municipality/city measured on the March $31^{\text {th }} i$ in year $t$ used as a proxy for economic activity of municipality/city, due to the markedly seasonal tourism activity it is expected that the number of employees measured on the March $31^{\text {th }}$ is not strongly correlated to the tourism activity which mainly takes place in the period from June to September, positive impact on net overall and abroad migration is expected

- $K_{i, t}$ [Number of Kindergartens] is the control variable of the number of kindergartens in municipality/city $i$ in year $t$ used as a proxy for the social standard of municipality/city that is expected to be a pull factor, hence positive impact on net overall and abroad migration is expected

- $d_{t}$ [European Union Accession] is the dummy variable for Croatia's accession to the EU, with the value of zero in the period from 2001 to 2012 and the value of 1 from 2013 to 2019

- $r_{t}$ [Recession] is the dummy variable for the 2008 and 2009 world economic recession, with the value of zero in the period 2002 to 2008 and from 2015 to 2019 and the value of 1 from 2009 to 2014 .

- $\alpha_{i}$ is the constant that changes with units

- $\lambda_{\mathrm{t}}$ is the constant that changes with time.

Taking as a point of departure the theoretical framework described for the understanding of the impact of tourism on migration, it is expected that the variable $O_{i, t}$ [Tourist Nights] will have a positive effect on both, net migration and net international migration, since tourism from the production perspective generates employment possibilities and potential for additional earnings for the inhabitants of the municipalities/cities and immigrants, and from a consumption perspective attracts permanent residency related to housing adjustments and retirement. Hence, tourism activity is a significant pull factor. 
ToSEE - Tourism in Southern and Eastern Europe, Vol. 6, pp. 357-373, 2021.

N. Ivandić: DOES TOURISM ACTIVITY AFFECT MIGRATION? EMPIRICAL EVIDENCE FROM ...

In addition to the theoretically expected positive effect of tourism activity on internal and international net migration, the positive effect of control variables is also expected. In other words, it is expected that the economic development of municipalities/cities, in the set models measured by the number of employees, and the social development of municipalities/cities, measured by the number of kindergartens, have the potential to dissuades people from emigrating and attract immigration. The dummy variables for European Union Accession and recession are expected to have a negative sign as both phenomena lead to emigration.

Specification of the Model I and Model II:

The model I: Net Migration

One-way fixed effect model:

$\Delta M_{i . t}=\alpha_{i}+\beta_{1} O_{i, t}+\beta_{2} E_{i, t}+\beta_{2} K_{i, t}+\beta_{3} d_{t}+\beta_{4} r_{t}+\epsilon_{i, t} ; i=1 \ldots, N ; t=1, \ldots, T$

Two-way fixed effect model:

$\Delta M_{i . t}=\alpha_{i}+\lambda_{t}+\beta_{1} O_{i, t}+\beta_{2} E_{i, t}+\beta_{2} K_{i, t}+\epsilon_{i, t} ; i=1 \ldots, N ; t=1, \ldots, T$

Model II: Net International Migration

One-way fixed effect model:

$\Delta I M_{i, t}=\alpha_{i}+\beta_{1} O_{i, t}+\beta_{2} E_{i, t}+\beta_{2} \mathrm{~K}_{i, t}+\beta_{3} d_{t}+\beta_{4} r_{t}+\epsilon_{i, t} ; i=1 \ldots, N ; t=1, \ldots, T$

Two-way fixed effect model:

$\Delta I M_{i, t}=\alpha_{i}+\lambda_{t}+\beta_{1} O_{i, t}+\beta_{2} E_{i, t}+\beta_{2} \mathrm{~K}_{i, t}+\epsilon_{i, t} ; i=1 \ldots \ldots, N ; t=1, \ldots \ldots, T$

\subsection{Data}

In the timeframe defined, 2002 to 2019 , the analysis is conducted at the granular level of Croatian municipalities and cities. Croatia has divided administratively into 428 municipalities and 128 cities, including the city of Zagreb, which has the special status of both city and county (Ministry of Justice and Administration 2021). In the 2002 to 2019 period, the number of cities and municipalities changed and the size and structure of the database used in the analysis have been adjusted to changes in the statuses of cities and municipalities.

Except for the city of Zagreb, the capital of the country, which in 2019 had a population of 807,254 , the average size of the population of municipalities and cities in 2019 was 5,870 .

The analysis has employed the following data from official statistics (Table 4). The number of inhabitants immigrating to and emigrating from municipalities in the 20022019 period (Net Migration) includes migrations to and from other municipalities and 
ToSEE - Tourism in Southern and Eastern Europe, Vol. 6, pp. 357-373, 2021.

N. Ivandić: DOES TOURISM ACTIVITY AFFECT MIGRATION? EMPIRICAL EVIDENCE FROM ...

cities, and to and from foreign countries. Data is retrieved from two sources: for the period 2002 to 2010 the data is taken from the electronic publication Croatian Bureau of Statistics: Population - Review by towns/municipalities, and for the 2011 to 2019 period from the electronic publication Croatian Bureau of Statistics: Towns in Statistics.

\section{Table 4: Descriptive Statistics}

\begin{tabular}{lrrrrr}
\hline Variable & Obs & Mean & Std. Dev. & Min & Max \\
\hline Net Migration & 7307 & -4.23 & 165.261 & -1586 & 3697 \\
Net International Migration & 7307 & -5.837 & 99.041 & -3099 & 3195 \\
International Emigration & 7307 & 40.401 & 198.428 & 0 & 7257 \\
Tourist Nights & 7329 & 155587.19 & 396551.34 & 0 & 4300003 \\
Employment & 7304 & 2531.267 & 16699.679 & 1 & 357379 \\
Number of Kindergartens & 7329 & 3.227 & 14.868 & 0 & 341 \\
European Union Accession & 7329 & .406 & .491 & 0 & 1 \\
Recession & 7329 & .333 & .471 & 0 & 1 \\
\hline
\end{tabular}

Note: While the total number of observations in the dataset is just above ten thousand, the unavailability of data for some municipalities for Tourist Nights and Employment restricts the sample size to 7304 observations.

Source: Author

The main independent variable Tourist Nights measures overnight stays in commercial tourism accommodation facilities in municipalities and cities for the period from 2002 to 2019. Because of the limited availability of the published data of official statistics as the level of individual municipalities and cities, for the 2002 to 2013 data from the database of the Institute for Tourism, based on Croatian Bureau of Statistics data, were used. For the period from 2014 to 2015 , data from the electronic publication Croatian Bureau of Statistics: Towns in Statistics were used, in which data for many municipalities are not published for reasons of confidentiality. For the period from 2016 to 2019, data from the Croatian Tourist Board eVisitor system were used.

Data for persons in paid employment in legal entities, the situation as of March, for the period from 2002 to 2010 are taken from annual Statistical reports: Employment and Wages, published by the Croatian Bureau of Statistics, while data from 2011 to 2019 are taken from the Croatian Bureau of Statistics electronic publication.

Sources of the data for the number of kindergartens are Croatian Bureau of Statistics electronic publications Basic Schools and Kindergartens and Other Legal Entities Implementing Preschool Education Programmes, End of School Year and Beginning of School/Pedagogic Year for the period from 2002 to 2010 and the electronic publication Croatian Bureau of Statistics: Towns in Statistics for the period from 2011 to 2019. 
ToSEE - Tourism in Southern and Eastern Europe, Vol. 6, pp. 357-373, 2021.

N. Ivandić: DOES TOURISM ACTIVITY AFFECT MIGRATION? EMPIRICAL EVIDENCE FROM ...

\subsection{Results}

Based on the parameters of four regressions estimated with the Ordinarly Least Squares (OLS) estimator, the analysis aims to comprehend the effect of tourism demand on net migration flows across municipalities of Croatia.

The research design allows an estimate of unbiased coefficients even if areas differ in unobservable characteristics, as long as these characteristics are invariant through time (such as institutional quality, geographical characteristics such as proximity to the Adriatic coast or border), as this difference is captured in the municipality fixed effect $\alpha_{i}$. Moreover, general changes in time or policy that happened at one point in time but affected all the areas equally are captured in the $\lambda_{t}$ that control for unobserved but areainvariant reforms and changes in time. It should be noted that after the inclusion of year fixed effects (two-way fixed effect model), estimating the effect of EU accession and recession are not possible as they are collinear with the year fixed effects and can be inferred from the estimates on the individual years.

The theoretical reason for using the fixed effect model stems from the fact that it is reasonable to expect that explanatory and control variables do not cover all factors related to migration in Croatia since it is determined by numerous internal institutional factors and geographical and historical characteristics of the area. These are, for example, population work ethics, national economic policy, national politics, historical nationalism and religious composition, which differ between municipalities and cities or change over time equally for all municipalities and cities.

Conducted F-tests of the joint significance of dummies in both regressions justify the use of both the one-way fixed effect model and the two-way fixed effect model (Table 5 and Table 6).

\section{The model I: Net Migration}

Regression analysis showed that tourism activity, measured by the number of nights, has a positive and significant effect on net migration, ceteris paribus in both tested regressions (Table 5). This suggests that tourism, through generating economic opportunity, has the potential to dissuade the population from emigrating. The estimated coefficient remains largely unchanged regardless of the estimated model indicating that there is no omitted variable bias in the model.

The employment variable, like the tourist nights variable, has a theoretically expected positive and significant effect on net migration, pointing to the importance of the economic development of municipalities and cities as a factor that can generate a positive relationship between the difference in in-migrating and out-migrating populations. On the other hand, the variable number of kindergartens, although it has a significant effect on net migration, does not have the expected positive impact on intra-Croatian net migration. This potentially indicates the negative sensitivity of migrating demographic segments to this element of the social standard, but also the importance of other economic 
ToSEE - Tourism in Southern and Eastern Europe, Vol. 6, pp. 357-373, 2021.

N. Ivandić: DOES TOURISM ACTIVITY AFFECT MIGRATION? EMPIRICAL EVIDENCE FROM ...

and institutional factors (such as working conditions, honesty and corruption, religious intolerance, nationalism) for migrations within Croatia.

The estimated coefficients of the variables employment and the number of kindergartens are stable in both regressions tested.

Table 5: Regression Results - Net Migration

\begin{tabular}{|c|c|c|}
\hline & $\begin{array}{l}\text { One-way fixed effect model } \\
\text { (equation 1) }\end{array}$ & $\begin{array}{l}\text { Two-way fixed effect model } \\
\text { (equation 2) }\end{array}$ \\
\hline Tourist Nights & $\begin{array}{l}0.000052 * * * \\
(0.000009)\end{array}$ & $\begin{array}{l}0.000058 * * * \\
(0.000009)\end{array}$ \\
\hline Employment & $\begin{array}{c}0.015000 * * * \\
(0.000766)\end{array}$ & $\begin{array}{c}0.014842 * * * \\
(0.000756)\end{array}$ \\
\hline Number of Kindergartens & $\begin{array}{c}-26.487927 * * * \\
(0.390264)\end{array}$ & $\begin{array}{c}-26.303077 * * * \\
(0.384358)\end{array}$ \\
\hline Recession & $\begin{array}{l}-3.346021 * \\
(1.783081)\end{array}$ & \\
\hline European Union Accession & $\begin{array}{c}-23.117900 * * * \\
(1.811562)\end{array}$ & \\
\hline Observations & 7,304 & 7,304 \\
\hline R-squared & 0.523742 & 0.541250 \\
\hline Municipality Fixed Effects & YES & YES \\
\hline Year Fixed Effects & NO & YES \\
\hline F test & $\begin{array}{l}\text { Test of joint significance of } \\
\text { dummies related to area } \\
\text { (municipalities/cities) } \\
F(458,6840)=29.00 \\
\text { Prob }>F=0.0000\end{array}$ & $\begin{array}{l}\text { Test of joint significance of } \\
\text { additional dummies related to } \\
\text { time (years) } \\
F(17,6825)=49.47 \\
\text { Prob }>F=0.000\end{array}$ \\
\hline
\end{tabular}

Note: Standard errors in parentheses

$* * * \mathrm{p}<0.01, * * \mathrm{p}<0.05, * \mathrm{p}<0.1$

Source: Author

In the one-way fixed effect model the variables recession and European Union Accession are significant and, as expected, have a negative effect on net migration. In the Appendix Table 7, I restimate the standard errors using heteroskedasticity and autocorrelation consistent (HAC) correction, known as Newey-West standard errors. This would correct for any presence of heteroscedasticity and serial correlation in the variance.

\section{Model II: Net International Migration}

Regardless of the model, the effect of tourism activity on net international migration is statistically significant and positive indicating a theoretically grounded expectation that tourism has the potential to dissuade the population from emigrating abroad or to induce im-migration (Table 6). Coefficients remain largely unchanged in both models implying that there is no omitted variable bias in the model. 
ToSEE - Tourism in Southern and Eastern Europe, Vol. 6, pp. 357-373, 2021.

N. Ivandić: DOES TOURISM ACTIVITY AFFECT MIGRATION? EMPIRICAL EVIDENCE FROM ...

Table 6: Regression Results - Net International Migration

\begin{tabular}{|c|c|c|}
\hline & $\begin{array}{l}\text { One-way fixed effect model } \\
\text { (equation 3) }\end{array}$ & $\begin{array}{l}\text { Two-way fixed effect model } \\
\text { (equation 4) }\end{array}$ \\
\hline Tourist Nights & $\begin{array}{c}0.000097 * * * \\
(0.000010)\end{array}$ & $\begin{array}{c}0.000113 * * * \\
(0.000010)\end{array}$ \\
\hline Employment & $\begin{array}{l}0.010857 * * * \\
(0.000868)\end{array}$ & $\begin{array}{c}0.010853 * * * \\
(0.000852)\end{array}$ \\
\hline Number of Kindergartens & $\begin{array}{l}1.112173 * * \\
(0.442351)\end{array}$ & $\begin{array}{c}1.395027 * * * \\
(0.433094)\end{array}$ \\
\hline Recession & $\begin{array}{l}-9.191179 * * * \\
(2.021062)\end{array}$ & \\
\hline European Union Accession & $\begin{array}{l}-44.453252 * * * \\
(2.053344)\end{array}$ & \\
\hline Observations & 7,304 & 7,304 \\
\hline R-squared & 0.780240 & 0.790802 \\
\hline Municipality Fixed Effects & YES & YES \\
\hline Year Fixed Effects & NO & YES \\
\hline F test & $\begin{array}{c}\text { Test of joint significance of } \\
\text { dummies related to area } \\
\text { (municipalities/cities) } \\
F(458,6840)=29.00 \\
\text { Prob }>\mathrm{F}=0.0000\end{array}$ & $\begin{array}{c}\text { Test of joint significance of } \\
\text { additional dummies related to } \\
\text { time (years) } \\
F(17,6825)=49.47 \\
\text { Prob }>\mathrm{F}=0.000\end{array}$ \\
\hline
\end{tabular}

Note: Standard errors in parentheses

$* * * \mathrm{p}<0.01, * * \mathrm{p}<0.05, * \mathrm{p}<0.1$

Source: Author

It is important to note that the variable Employment has the expected positive and significant effect on net international migration, as well as the variable Number of Kindergartens as a proxy of social development municipality and cities, which in the context of international migration takes the theoretically expected impact. The estimated coefficients of these variables are stable in both regressions tested. The variables Recession and European Union Accession in the One-way fixed effect model are significant and, as expected, have a negative effect on net international migration.

In the Appendix Table 7, I restimate the standard errors using heteroskedasticity and autocorrelation consistent (HAC) correction, known as Newey-West standard errors. This would correct for any presence of heteroscedasticity and serial correlation in the variance.

\section{CONCLUSION}

The main contribution of this paper is the novel use of such detailed data, which spans two decades, at the detailed geographical level. This generates empirical insights with high levels of external validity. A further important aspect of the paper is the analysis of the connection between population migration and tourism activity in the context of Croatia's accession to the European Union. 
ToSEE - Tourism in Southern and Eastern Europe, Vol. 6, pp. 357-373, 2021.

N. Ivandić: DOES TOURISM ACTIVITY AFFECT MIGRATION? EMPIRICAL EVIDENCE FROM ...

In addition to the verification of the theoretically grounded expectation that tourism activity of the theoretically well-founded expectation that tourism has the potential to dissuade the population from emigrating, as well as to generate incentives for immigrating into some area, the study's conclusions have policy relevance as they indicate opportunities to reduce the net migration for less developed tourist areas and the role of employment as a mitigator of population decline. With the premise that it is necessary to run a sustainable policy of tourist development compatible with destination bottlenecks, constraints and risks (Ivandić et al. 2021) this implies constant raising of the level of the knowledge and capacity of the local population concerning tourism, the systematic encouragement of the development of micro, small and medium-sized enterprises in tourism and the obviation of developmental constraints from the institutional setting.

The key limitation of the analysed models is the availability of data at a granular geographic level. Sectoral Gross Value Added data, wage data, or similar indicators of economic activity are not available at the municipality and city level. Equally, neither data on the monetary aspects of tourism activity nor data on employment in tourism, especially in the context of the sharing economy, are available. An important limitation of the analysis stems also from the lack of data on age segments of the migrant population, especially because seasonal demand for labor during several of the summer months does not allow or incentivize employees to establish permanent residence. Given the high importance of tourism for the Croatian economy, these restrictions impose the need to expand the information base of official statistics, but also to develop an additional set of adequate proxy variables.

\section{REFERENCE}

Akrap, A. (2019), “Stanovništvo u Hrvatskoj: čimbenici silaznih trendova”, Obnovljeni Život, Vol.74, No. 3 , pp. 335-350.

Baltagi, B.H. (2005), Econometric Analysis of Panel Data, 3rd ed., John Wiley \& Sons, Chichester.

Belem Barbosa, B., Santos, C.A. and Santos, M. (2020), "Tourists with migrants' eyes: the mediating role of tourism in international retirement migration", Journal of Tourism and Cultural Change, pp 1-15. doi: $10.1080 / 14766825.2020 .1727489$

Bell, M., and Ward, G. (2000), "Comparing Temporary Mobility with Permanent Migration", Tourism Geographies, Vol. 2, No. 1, pp. 97-107.

Croatian Bureau of Statistics (2016), First release Population estimate of Republic of Croatia, 2015, No. 7.1.3. Croatian Bureau of Statistics (2020), First release Migration of population of Republic of Croatia, 2019, No. 7.1.2.

Croatian Bureau of Statistics (2020), First release Population estimate of Republic of Croatia, 2019, No. 7.1.3

De Haas, H. (2010), Migration transitions A theoretical and empirical inquiry into the developmental drivers of international migration, Working Papers, Paper 24, International Migration Institute (IMI), Oxford Department of International Development (QEH), University of Oxford, Oxford.

Dwyer L., Seetara, N., Forsyth P. and King, B. (2014), "Is the Migration-Tourism Relationship only about VFR?", Annals of Tourism Research, Vol. 46, No. 3, pp. 130-143.

European Commission (2020), Factsheet: New Pact on Migration and Asylum, https://ec.europa.eu/info/sites/info/files/new-pact-on-migration-and-asylum-package_1.pdf

Eurostat (2019). Tourism Satellite Accounts in Europe, 2019 edition, Publications Office of the European Union, Luxembourg.

Eurostat (2021), Migration and migrant population statistics, viewed 18 April 2021, https://ec.europa.eu/eurostat/statistics-explained/index.php/Migration_and_migrant population_statistics\#Migration_flows: Immigration_to_the_EU_from_non-member_countries was_2.7_million_ in_2019 
ToSEE - Tourism in Southern and Eastern Europe, Vol. 6, pp. 357-373, 2021.

N. Ivandić: DOES TOURISM ACTIVITY AFFECT MIGRATION? EMPIRICAL EVIDENCE FROM ...

Franc, S., Čeh Časni, A. and Barišić, A. (2019), "Determinants of migration following the EU enlargement: A panel data analysis", South East European Journal of Economics and Business, Vol. 14, No. 2, pp. $13-22$.

Goldner Lang, I. and Lang, M. (2019), "Mračna strana slobode kretanja: kada su u koliziji interesi pojedinca i društva", Migracijske i etičke teme, Vol. 35, No. 1, pp. 89-116.

Ivandić, N., Telišman-Košuta, N. and Carić, H. (2021), "Suvremeno poimanje turističkog nosivog kapaciteta kao platforme za upravljanje održivim destinacijama”, Znanstveno vijeće za turizam i prostor, Hrvatska akademija znanosti i umjetnosti, on-line kolokvij Turistički time out - Trenutak za novo promišljanje turizma i prostora, in the process of publication.

Kahanec, M., Zaiceva, A. and Zimmermann, K. F. (2009), Lessons from migration after EU enlargement, IZA Discussion Papers, No. 4230, Institute for the Study of Labor (IZA), Bonn.

Kumpikaite, V. and Zickute, I. (2012), "Synergy of Migration Theories: Theoretical Insights", Inzinerine Ekonomika-Engineering Economics, Vol. 23, No. 4, pp. 387-394.

Massey, D.S., Arango, J., Hugo, G., Kouaouci, A., Pellegrino, A. and Taylor, J.E (1993), "Theories of International Migration: A Review and Appraisal”, Population and Development Review, Vol. 19, No. 3, pp. 431-466.

Massey, D.S., Arango, J., Hugo, G., Kouaouci, A., Pellegrino, A. and Taylor, J.E (1999), Worlds in Motion: Understanding International Migration at the End of the Millennium, Clarendon Press, Oxford.

Ministarstvo pravosuđa i uprave (2021), 100613-Kopija općine_gradovi_RH-1.xls, retrived from https://mpu.gov.hr/o-ministarstvu/ustrojstvo/uprava-za-politicki-sustav-i-opcu-upravu/lo kalna-ipodrucna-regionalna-samouprava/popis-zupanija-gradova-i-opcina/2231918.4.20 21

Möller, P. and Amcoff, J. (2018), "Tourism's localised population effect in the rural areas of Sweden", Scandinavian journal of hospitality and tourism, Vol. 18, No. 1, pp. 39-55.

Pavić, D. and Ivanović, I. (2019), "Razlike u prikupljanju migracijskih podataka: usporedba Hrvatske i odabranih europskih zemalja", Migracijske i etničke teme, Vol. 35, No. 1, pp. 7-32.

Rauhut, D. (2010), "Viewpoint: Adam Smith on migration", Migration Letters, Vol. 7, No. 1, pp. 105-113.

Salazar, N.B. (2020), "Labour migration and tourism mobilities: Time to bring sustainability into the debate", Tourism Geographies, pp. 1-11. https://doi.org/10.1080/14616688.2020.1801827

Santos, R. Castanho, R.A. and Lousada, S. (2019), "Return Migration and Tourism Sustainability in Portugal: Extracting Opportunities for Sustainable Common Planning in Southern Europe", Sustainability, Vol. 11, No. 6468, pp. 1-21. doi: 10.3390/su11226468

Schewel, K. (2020), "Understanding Immobility: Moving Beyond the Mobility Bias in Migration Studies", International Migration Review, Vol. 54, No. 2, pp. 328-355. doi: 10.1177/0197918319831952

Toker, A. and Kozak, N. (2020), "The role of tourism related migrations on sociocultural change: The case of Didyma", Advances in Hospitality and Tourism Research, Vol. 8, No. 2, pp. 393-418

Troskot, Z., Prskalo, M.E. and Šimić Banović, R. (2019), "Ključne odrednice iseljavanja visokokvalificiranog stanovništva: Slučaj Hrvatske s komparativnim osvrtom na nove članice EU-a”, Zbornik radova Pravnog fakulteta u Splitu, Vol. 56, No. 4, pp. 877-904.

Vuin, A., Carson, D.A., Bradley Carson, D. and Garrett, J. (2016), "The role of heritage tourism in attracting "active" in-migrants to "low amenity" rural areas", Rural Society, Vol. 25, No. 2, pp. 134-153.

Williams, A.M. and Hall, C.M. (2000), "Tourism and migration: new relationships between production and consumption", Tourism Geographies, Vol. 2, No. 1, pp. 5-27.

Williams, A.M. and Hall, C.M. (2002), "Tourism, migration, circulation and mobility. The contingencies of time and place", in Hall, C.M. and Williams, A.M. (Eds.), Tourism and Migration. New Relationship between Production and Consumption, Kluwer Academic Publishers, Dordrecht.

World Tourism Organization (2009), Tourism and Migration - Exploring the Relationship between Two Global Phenomena, World Tourism Organization: Madrid. 
ToSEE - Tourism in Southern and Eastern Europe, Vol. 6, pp. 357-373, 2021.

N. Ivandić: DOES TOURISM ACTIVITY AFFECT MIGRATION? EMPIRICAL EVIDENCE FROM ...

\section{APPENDIX}

Table 7. Inclusion of Heteroskedasticity and Autocorrelation Robust Standard errors

\begin{tabular}{|c|c|c|c|c|}
\hline VARIABLES & $\begin{array}{c}(1) \\
\text { Net. Migration } \\
\end{array}$ & $\begin{array}{c}(2) \\
\text { Net. Migration } \\
\end{array}$ & $\begin{array}{c}(3) \\
\text { Net. Int. Migration } \\
\end{array}$ & $\begin{array}{c}\text { (4) } \\
\text { Net. Int. Migration } \\
\end{array}$ \\
\hline Tourist Nights & $\begin{array}{c}0.000097 * * * \\
(0.000025)\end{array}$ & $\begin{array}{c}0.000113 * * * \\
(0.000024)\end{array}$ & $\begin{array}{c}0.000052^{* *} * \\
(0.000022)\end{array}$ & $\begin{array}{c}0.000058 * * * \\
(0.000020)\end{array}$ \\
\hline Employment & $\begin{array}{c}0.010857 \\
(0.010138)\end{array}$ & $\begin{array}{c}0.010853 \\
(0.010094)\end{array}$ & $\begin{array}{c}0.015000 \\
(0.011185)\end{array}$ & $\begin{array}{c}0.014842 \\
(0.011158)\end{array}$ \\
\hline $\begin{array}{l}\text { Number of } \\
\text { Kindergartens }\end{array}$ & 1.112173 & 1.395027 & $-26.487927 * * *$ & $-26.303077 * * *$ \\
\hline Recession & $\begin{array}{c}(3.770532) \\
-9.191179 * * * \\
(2.008572) \\
-44453252 * * *\end{array}$ & (3.731682) & $\begin{array}{c}(4.817606) \\
-3.346021 \\
(2.046151) \\
-23.17900 * * *\end{array}$ & (4.779532) \\
\hline & $(2.801350)$ & & (3.147353) & \\
\hline $\begin{array}{l}\text { Observations } \\
\text { R-squared } \\
\text { Municipality Fixed } \\
\text { Effects } \\
\text { Year Fixed Effects }\end{array}$ & $\begin{array}{c}7,304 \\
0.780240 \\
\quad \text { YES }\end{array}$ & $\begin{array}{c}7,304 \\
0.790802 \\
\text { YES }\end{array}$ & $\begin{array}{c}7,304 \\
0.523742 \\
\text { YES }\end{array}$ & $\begin{array}{c}7,304 \\
0.541250 \\
\text { YES }\end{array}$ \\
\hline
\end{tabular}

Note: Robust HAC standard errors in parentheses

$* * * \mathrm{p}<0.01, * * \mathrm{p}<0.05, * \mathrm{p}<0.1$

Neven Ivandić, $\mathrm{PhD}$, senior research fellow

Institute for Tourism

Vrhovec 5, Zagreb, Croatia

+385-1-390-9666

neven.ivandic@iztzg.hr 